\title{
EVALUATION OF "STRESS RELIEF" DIETARY SUPPLEMENT ON ANIMAL STRESS LEVEL AND LOCOMOTION
}

\author{
Šimons Svirskis ${ }^{1,2, \#}$, Linda Klimavičiusa ${ }^{1}$, and Zane Dzirkale ${ }^{1}$ \\ ${ }^{1}$ Faculty of Medicine, University of Latvia, 1 Jelgavas Str., LV-1004, Rīga, LATVIA \\ ${ }^{2}$ Augusts Kirhenšteins Institute of Microbiology and Virology, Rīga Stradinš University, 5a Rātsupītes Str., LV-1067, Rīga, LATVIA \\ \# Corresponding author, ssvirskis@latnet.lv \\ Communicated by Vija Zaiga Kluša
}

\begin{abstract}
Search of new approaches for harmless, non-medication treatment of body dysfunctions is still on the agenda of vet and human practitioners and researchers as well. This study presents evaluation of the effect of "Stress Relief" dietary supplement (SR) on mice behaviour under different acute short-term stress conditions and treatment duration. Five experiments were performed and in each 40 animals were randomly split into four (I-IV) groups, where I and II - non-stressed mice, III and IV - stressed animals, I and III received water with trace mineral solution (TMS), II and IV received water with SR. As stress factors, forced swimming, rodent predator odour or both together were applied. Locomotor activity under normal and stress conditions in Open Field were observed and measured by a SMART video-tracking system. Blood glucose level was measured as well. SR showed a reversal of stress-decreased locomotor activity in all stress models - distance walked increased almost twice $(\mathrm{p}<0.0001)$, central zone crossings and time spent in it were 2-4 times greater than in the control group $(\mathrm{p}<0.0001$ and $\mathrm{p}=0.0002$, respectively), and fast movement episodes and maximal speed increased by 50-200\%. In addition, complete normalisation of stress-induced elevation of blood glucose level $(\mathrm{p}<0.0001)$ was noted. These results demonstrate for the first time that the effect of "Stress Relief" formula (water additives-minerals processed by know-how way in Vital Force Technology using Dr. Yury Kronn method) can be observed in laboratory animals, and that the effects are significant and repeatable. SR shows fear- and stress-reducing activity, which does not sufficiently differ between 7-, 9-, 14-, 28- and 32-day treatment regimes.
\end{abstract}

Key words: "Stress Relief" dietary supplement, laboratory mice, stress, stress reduction.

\section{INTRODUCTION}

There is a large number of published scientific studies that describe the effects of multi-directed negative influence of acute and chronic distress on the human body and a person's general wellness, causing a long-term decrease of quality of life (Sonnentag and Fritz, 2006; Wallace, 2012; van Reedt Dortland et al., 2013; Jafari et al., 2017). Therapeutic approaches to diminish stress-induced disturbances have been widely proposed by many authors (Qi et al., 2008; Mao et al., 2010; Li et al., 2013). However, the treatment effectiveness of typical Western medicine standard approaches in many cases seems to be insufficient, disputable or sometimes even controversial, due to side effects caused by a range of inadequate influences on the cellular signal transduction pathways by inappropriate usage of medicines (Forster et al., 2003; Null et al., 2006; Axe, 2010).

In treatment of various mental diseases, the role of drug therapy has become weaker and weaker and it was proposed that a phytotherapeutic approach could be a promising strategy (Gerbarg and Brown, 2013). A growing number of patients with mood disorders are using complementary and alternative medicine (CAM) interventions (Andreescu et al., 2008; Ravidran and Da Silva, 2013). Recently, physicians have demonstrated changed attitudes towards CAM, and many of them have stressed the need for it (Kim and Cho, 2014; Wahner-Roedler et al., 2014; Wardle and Adams, 2014). Some of the more natural and harmless approaches for treating stress - modalities of "energy medicine," also known as vibrational medicine, have been proposed (Gerber, 2001; Oschman, 2003).

Very intriguing presentations and articles about capture of the so-called "subtle energy", and reports on effects of different "subtle energy" mixture formulas on plant growth, on human well-being, some physiological functions and also in vet praxis are found (Kronn et al., 2001; Kronn, 2009). Experiments on a wide variety of effects produced by "subtle energy" preparations on chemical and physical processes 
and living organisms have been reported in several articles (Lu, 1997; Swanson, 2009; Anonymous, 2013). It was established that different energy patterns can produce different structures of mineralised water (Rao et al., 2008), and various methods have been explored for creating "subtle energy" patterns, based on the particular purpose behind each experiment. One of the methods used by Dr. Kronn (http://www.dryurykronn.com) was to initiate the vibration of plasma by applying sub-harmonics of light frequencies of the electronic transitions in atoms of the periodic table, belonging to the audio frequency band. It has been experimentally proven that "subtle energy" patterns created with this method and infused into spring water significantly enhance germination and seedling development of 7-year-old seeds (Kronn, 2003). The author later described how different "subtle energy" patterns were generated using electron-ion plasma created by an electrical discharge in the inert gasses, and showed that the patterns generated by the equipment can be infused in various substances by high level elaborated technology (Kronn, 2009).

Taking into account the above, we decided to explore one of the "subtle energy" energetic formulas designed by Energy Tools Int. using Vital Force Technology — "Stress Relief" on laboratory mice under different treatment duration and stress situations.

This study documents the results of three-year research employing contemporary animal models typically used in neuroscience. The study is based on previously reported results about the effect of this formula on water physical and physicochemical properties (Anonymous, 2013). A number of non-published, repeated observations of health practitioners have previously noted the anti-stress effectiveness of "Stress Relief" formula. This motivated us to perform a study on the effect of this dietary supplement on behaviour of laboratory rodents exposed to different short-term stress conditions. We used animals to exclude the human factor, i.e. autosuggestion.

\section{MATERIALS AND METHODS}

Animals. Rodent species, such as mice and rats, are commonly used to study different aspects of brain pathogenesis (Cryan and Holmes, 2005; Young et al., 2007; Bussey et al., 2012). Mice among rodents are particularly widely used in bio-behavioural studies and in neuroscience research (Crawley, 2008; Heredia et al., 2014).

Two hundred male mice of the C57BL/6J strain (considered as the "gold standard" in neurobehavioral research) (Berry et al., 2012; Heredia et al., 2014) weighing between 20 and 22 g (Laboratory of Experimental Animals, Rīga Stradiňš University, Latvia), aged 6-7 weeks, considered to approximate human peri-adolescence (Hefner and Holmes, 2007), were used. The animals were put in two identical, but separate, isolated cabinets (Scantainer, Scanbur) and housed on a 12-hour light/dark cycle in a controlled temperature (22 \pm $\left.2{ }^{\circ} \mathrm{C}\right)$ and humidity $(50 \pm 10 \%)$, and standard white noise.
Mice had constant access to drinking water. Housing conditions were identical.

Experimental design. Our study was split into three parts and five experiments were performed using this design. The scheme of the five experiments is presented in Figure 1.

In each of the five experiments, animals were randomly assigned into four experimental groups, ten animals per group: I - TMS (control group drinking tap water mixed with the appropriate amount of trace mineral solution (TMS) not infused with subtle energy), II - SR (mice drinking tap water plus TMS infused with Stress Relief (SR) subtle energy pattern), III - TMS-S (second control group of mice drinking tap water plus TMS without subtle energy infusion; exposed to short-term stress), IV - SR-S (mice drinking tap water plus TMS with infusion of SR; exposed to short-term stress).

In the first part of our study we performed one 9-day experiment (duration was established in pilot experiments as more or less sufficient for detection of statistically significant changes) using a forced swimming stress (FSS) model (Berry et al., 2012). The animals for simultaneous observation were arranged as represented in Figure 1. Ten behaviour recording sessions were performed and within each of the ten sets, animals for simultaneous observation were arranged in the following way - I, II, III, IV.

In the second part of study, predator odour stress (POS) mode (Staples, 2010) was applied. In this part we carried out three experiments with different time schedules (7-, 14-, and 28-day) to test for time-effect relationships (Fig. 1). Firstly, five control experiments without odour stress factor were done (in each of them mice were arranged from groups in the following way - I, I, II, II), and then in the next five sessions mixed cat-rat odour was applied to the animals (mice were arranged in the following way - III, III, IV, IV).

In the last part of the study, which was scheduled after computing of data and obtaining results from the odour stress studies, one 32-day (approximately 1 month) experiment was done with applying both stress factors - FSS and POS (Fig. 1). In this final experiment mice that received stress were grouped similarly as described in the second part (see above). In all cases animals were allowed to have full access to food and water.

Control animals (groups I and III) were housed separately from animals that received SR in drinking water (groups II and IV).

Energy pattern. "Stress Relief" (SR) Trace Minerals dietary supplement (Fig. 2) is presented as a SR formula infused into concentrated trace minerals $(20 \%)$; it is a commercial product that was designed by Dr. Yury Kronn using Vital Force Technology

(http://www.vitalforcetechnology.com). The product used in this study was obtained from Energy Tools International company (http://www.energytoolsint.com). 

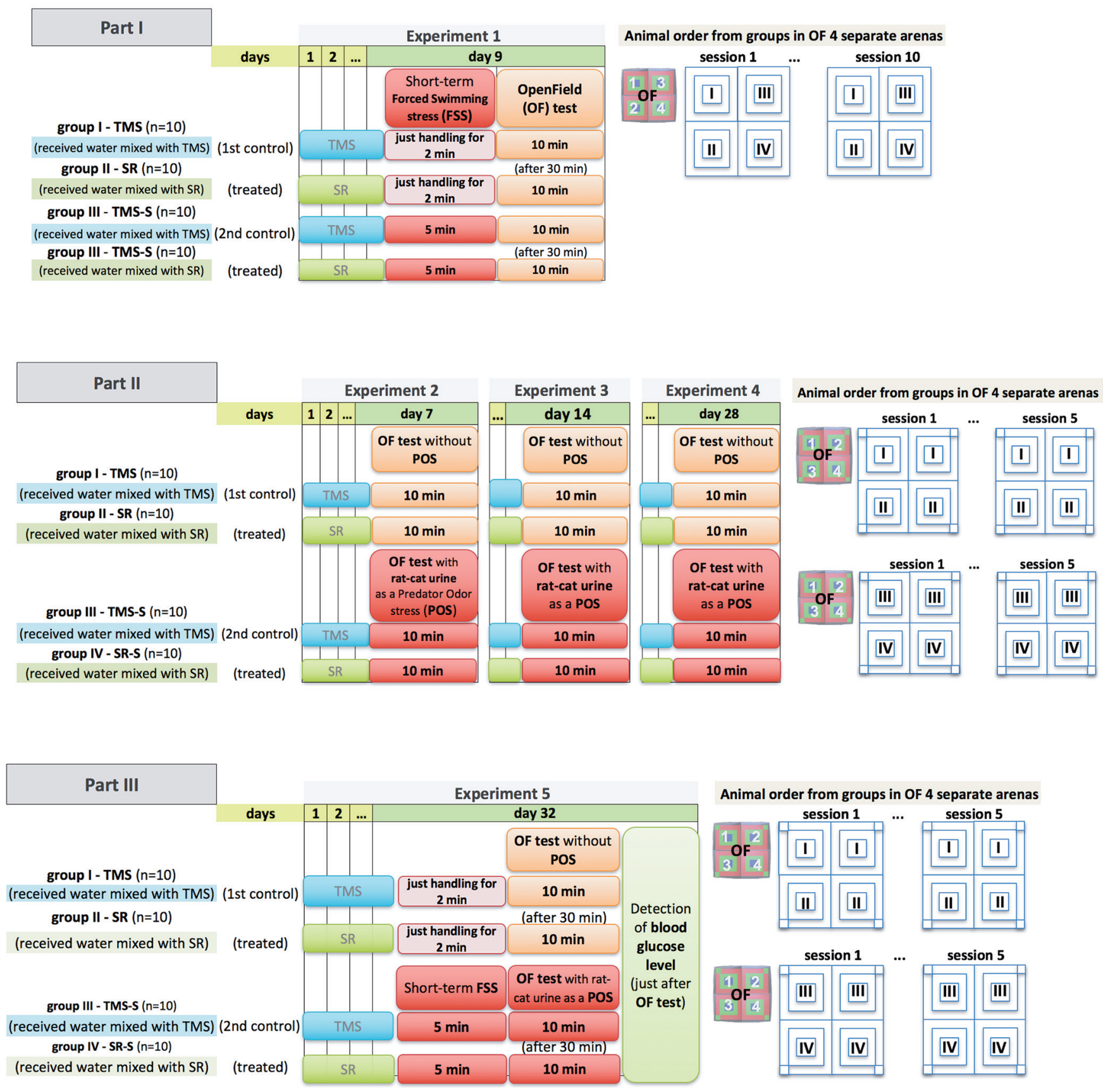

Fig. 1. The schedule and study design. TMS, trace mineral solution, SR, "Stress Relief" trace minerals dietary supplement infused in TMS. 1, 2, 3, 4, individual separate compartments in an open-field (OF) arena. Time in min indicates duration of applied test or stress situation.

SR was added to the drinking water for mice. The concentration of the infused minerals in this solution was made equipotent to the suggested double dosage for an adult human taking SR-infused trace minerals, i.e. in the amount of 22 drops three times per day (66 drops daily). Appropriate calculations were made taking into account that the normal water intake of mice is approximately $4-5 \mathrm{ml} / 24 \mathrm{~h}$ (Anonymous, 2017b). For ten mice per cage $250 \mathrm{ml}$ tap water was provided and was replaced after four days with fresh water. Four drops of "clean" (not infused with SR) trace mineral solution (TMS) was dissolved in $500 \mathrm{ml}$ of tap water, and then divided in two equal parts $-250 \mathrm{ml}$ per bottle for each control group (group I — TMS and group III — TMS-S).
Fig. 2. "Stress Relief" Trace Minerals dietary supplement from Energy Tools International.

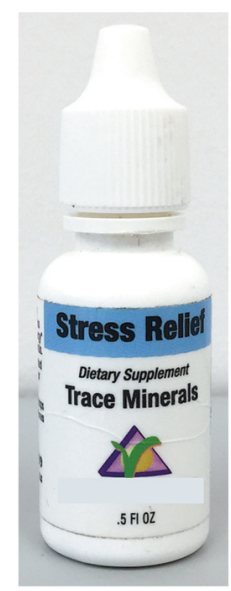


The same procedure was used for animal groups II (SR) and IV (SR-S); but instead of the un-infused trace mineral solution, four drops of solution infused with SR energy pattern was added. Animals had a free access to water during all experiments in this study.

Chromatography analysis of samples. To test for presence of additional chemicals in the drinking water used in all five experiments, samples of tap water mixed with appropriate amounts of TMS, and samples mixed with SR infused TMS, were analysed by Waters Acquility UPLC chromatography system using Symmetry C18 $4.6 \mu \mathrm{m} \times 100 \mathrm{~mm}$ columns with mobile phase containing $50 \%$ acetonitrile/50\% water (Anonymous, 2017f).

Behaviour studies. Anxiety-like behaviour and exploration were measured using a pharmacologically well-validated exploration-based test - the Open Field Test (Gould et al., 2009) combined with Forced Swimming Test (Ritchie et al., 2004) or predator odour application or both together.

Open field test. The Open Field test (OF) is a validated method commonly used in neuroscience and pharmacology that assays aspects of locomotor, exploratory and emotional behaviour (risk assessment and anxiety-like behaviour that is caused by different stress factors) in response to a novel environment (Berry et al., 2012; Heredia et al., 2014). Rodents typically spend a significantly greater amount of time exploring the periphery of the arena - usually in contact with the walls (thigmotaxis) - than the unprotected centre area. Mice that spend significantly more time exploring the unprotected centre area demonstrate anxiolytic-like stresssuppressive baseline behaviour (Gould et al., 2009).

The expected pattern of behaviour is that animals will tend to thoroughly explore a new arena initially, and eventually habituate to the open field. The test can be repeated as long as due care is taken to ensure that both controls and treatment groups undergo all preceding procedures in an identical manner. In our studies, each trial set (out of ten for each of five experiments) four mice (one of each group) were observed simultaneously (see details in Fig. 1). The primary measures in OF were established for further analysis: locomotor activity (track length, velocity, characteristic of movements, etc.), exploration (zone crossings), and anxietylike behaviour - decreased entry and activity in the centre of the arena (experiment 1) and corner zone where stressor agent was applied (experiments 2, 3, 4, 5).

A $1 \times 1$ meter rectangular arena divided into four equal parts was used as the OF environment. The OF behaviour test involved placing an animal in a separate arena of a $50 \times 50 \mathrm{~cm}$ white-painted plastic platform with $25-\mathrm{cm}$ high surrounding walls, illuminated with white $100 \mathrm{Lx}$ scattered light from a rectangle light source placed $1 \mathrm{~m}$ above the arena. The total distance travelled in the arena reflects general exploratory activity that can be changed by locomotor ability, and is reduced in the case of sedation, prior stress, paralysis, or impairment of movements, and conversely increased in case of excitation or anxiolytic and stress-decreasing influences (Gould et al., 2009; Marzotto et al.,
2012). Spontaneous Motor Activity Recording and Tracking (SMART) software (PanLab, Barcelona, Spain) combined with a video camera was used as a digital video-tracking system to monitor the location of the animal within the OF (Gould et al., 2009; Anonymous, 2017a).

For analysis by SMART and depending on the experiment design, the OF was divided into three virtual zones (outer perimeter, middle part, and central zone) or four zones (additional corner zone). In each 10-min tracking period session, four mice (one from each group) were gently put into the centre of separate arenas, and locomotor behaviour was registered for the following 10 minutes. All sessions were recorded with a video-tracking camera.

The SMART software allowed us to automatically trace the position and movements of the animals and calculate the following parameters: zone crossings (N.Ent.), distance walked (Dist), maximal velocity (V.Max), resting time (Res.T.), slow movements (Mov.S.), fast movements (Mov.F.), central zone crossings (CZone) and time spent in zones.). Our main areas of interest were the following:

- zone crossings (zone entrances, N.Ent., as number),

- the distance walked (Dist, in $\mathrm{cm}$ ),

- central zone crossings (as number),

- corner zone crossings (as number).

The floor of the test arenas was cleaned thoroughly with cotton and $70 \%$ ethanol between subjects. All observations were performed during daytime from 9.00 till 16.00 at normal room temperature and white noise level.

Stress condition. In the first part, according to our study design (Fig. 1), 30 minutes before the OF procedure on Day 9 of the experiment 1 (as well as on Day 32 of the experiment 5 - part 3), animals of the III and IV groups were subjected to a stressful situation, using inescapable forced-swimming in the Forced Swim Test (FST). This was conducted similar to the well-known Porsolt test, which is widely used in neuroscience to detect antidepressant-like activity of physical and chemical factors (Berry et al., 2012; Anonymous, 2017 c). The method is based on the assumption that an animal will try for some time to escape an aversive (stressful) stimulus (in this case, being put into water) before it gives up and floats in the water without active movements; the immobilisation time is registered (Ritchie et al., 2004; Anonymous, 2017c). In our study, we simply utilised the idea of short-term stress caused by forced swimming in a particular environment. Mice were placed as in the Porsolt procedure in transparent plastic cylinders $(12.5-\mathrm{cm}$ diameter, $30-\mathrm{cm}$ height) containing $20 \mathrm{~cm}$ of water at $22-23^{\circ} \mathrm{C}$ and were left there for five minutes (instead of six min as in the Porsolt test) to receive short-term stressful stimuli (inescapable forced swimming) without registration of immobilisation time after first two minutes of swimming, then removed, dried and put in the home cage for a later OF test. 
In the second part of our study (three experiments with different SR drinking duration - 7, 14, and 28-days) another mild short-term stress model, i.e. predator odour stress, was applied (Ritchie et al., 2004; Smith et al., 2006; Staple, 2010). It is well known that mice are innately fearful of cats and rats, which are their predators. The urine of these predators contains major urinary proteins (MUPs), which are a very strong stress signal for mice and elicit robust defensive responses including avoidance and the release of stress hormones (Luo, 2016). In experiment 2, 3, and 4, mice were exposed to mixed cat/rat urine soaked sawdust that was packed in a small gauze bag and placed in each corner of the OF arena.

In the third study part with SR drinking duration for 32 days (experiment 5), both stress factors were applied to test the effect of SR in this combined stress model.

Blood glucose level detection. It is well known that stress hormones are released and blood glucose level increases under stress conditions. In stressful situations an organism prepares itself with accumulation of energetically important resources, like increasing blood glucose level to realize fight or flight strategy. The most stressful environment was provided in the last fifth experiment, where two stress factors were combined, with one following the other. It was hypothesised that the blood glucose level would be elevated. On the last, 32nd day, after OF tracking each mouse was subjected to blood sampling from tail vein for analysis of blood glucose using an ACCU-CHECK Nano glucometer.

The procedures in this study were conducted in accordance with the Council for Ethical Treatment of Animals in Latvia and the Ethics Committee for Laboratory Animal Use in Biomedical Experiments. All efforts were made to minimise animal suffering and to reduce the number of animals used.

Statistical analysis. To test whether the collected numerical data are normally distributed, the D'Agostino \& Pearson and Shapiro-Wilk normality tests were applied. The comparison of means between different groups of numerical variables was performed using one-way or two-way ANOVA. Homogeneity of variances were tested using Brown-Forsythe and Bartlett's tests. If data were not normally distributed (also in a case of unequal SD), the comparison of means between different groups was switched to medians with non-parametric one-way ANOVA on ranks or Kruskal-Wallis test followed by post-hoc analysis. Dynamic changes of measured parameters and differences among groups were assessed with two-way ANOVA (time X treatment) and a subsequent post-hoc test. In all cases the two-stage step-up method of Benjamin, Krieger and Yekutieli as post-hoc analysis was used. As the data in some cases had a logarithmic distribution tendency, to illustrate results more clearly a logarithmic Y scale and geometric mean $\pm 95 \%$ CI (confidence interval) was used. Results in Figure 6 and Figure 10 were presented as medians and interquartile ranges (IQR). As an additional test of the effect of SR, correlation analysis between control and SR groups in each experiment was done. A $p$-value less than $0.05(p<$ 0.05 ) were considered as statistically significant. All the graphs, calculations, and statistical analyses were performed using GraphPad Prism software version 7.0 for Mac (GraphPad Software, San Diego, California, USA).

\section{RESULTS}

Analysis of water samples. Analysis of drinking water samples used in this study did not reveal the presence of any substantial chemical impurities, including ions and/or additional chemicals by chromatography method (Fig. 3). Thus, we can conclude that there is no other than water chemical matter that could affect the obtained results.

Open field test. In all experiments conducted, we obtained rather similar results that confirmed a significant effect of SR energy pattern on behaviour, especially locomotor exploration activity of stressed and also non-affected animals. Pilot studies (5-day SR intake) allowed us to optimise further experiments on stress condition and application of SR. It was observed that a 5-min period of inescapable FSS was sufficient to get obtain significant decrease of mice locomotor activity in OF environment. Further, instead of a 5-day SR drinking regime (where the SR effect was very weak),

$\mathbf{A}$

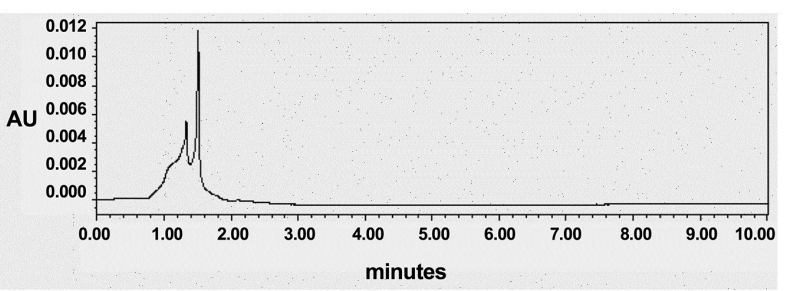

B

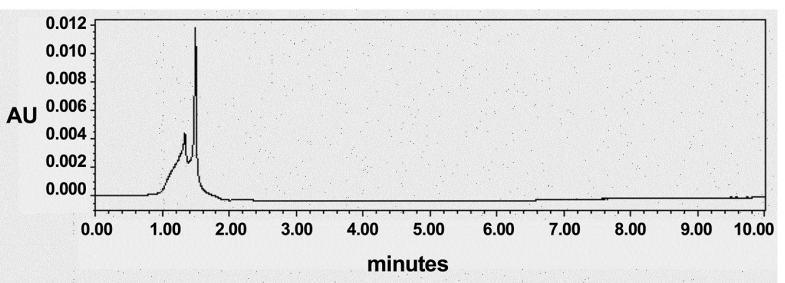

C

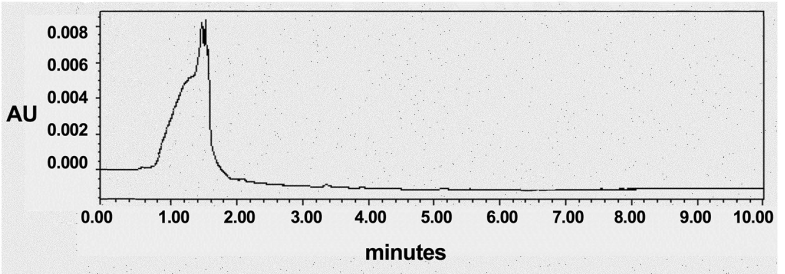

D

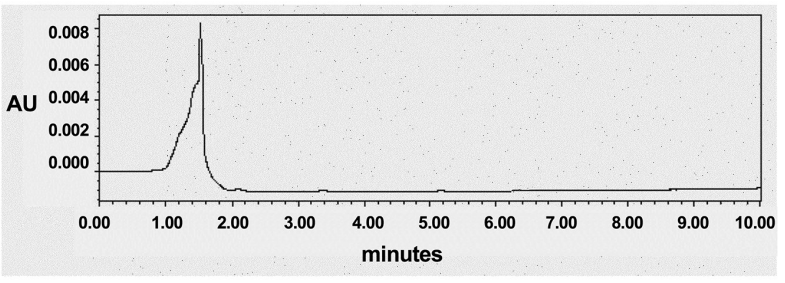

Fig. 3. Chromatograms of water samples using PDA detector at $254 \mathrm{~nm}$. A, tap water, B, purified water, C, tap water mixed with appropriate amount of TMS (trace mineral solution), D, tap water mixed with appropriate amount of SR ("Stress Relief" trace minerals dietary supplement) infused TMS. 

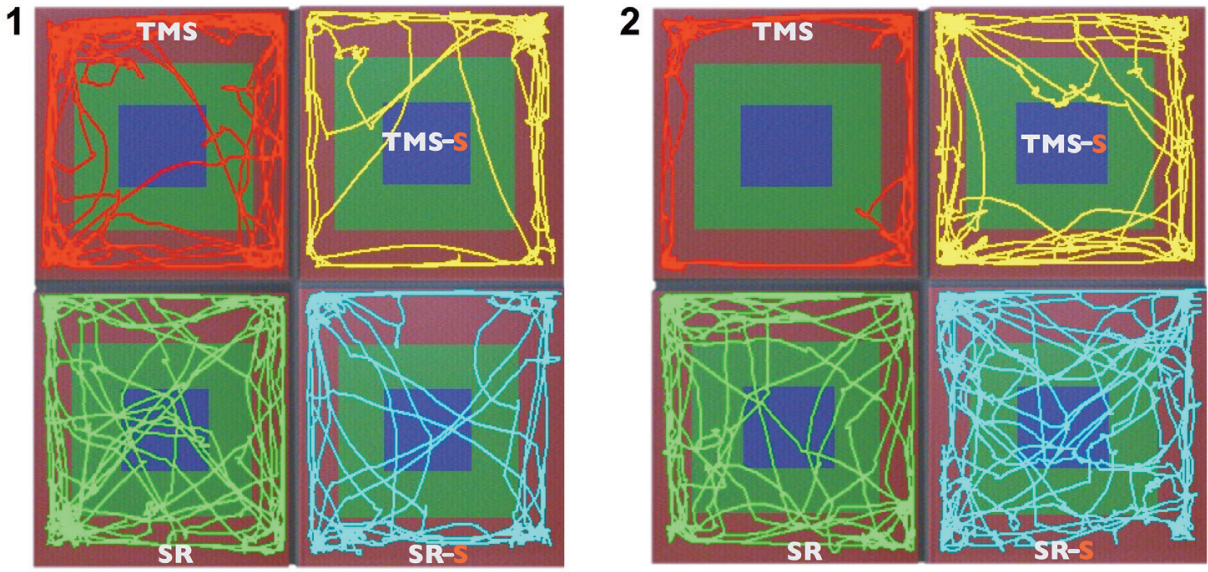

Fig. 4. Two examples $(1,2)$ of tracking sessions of mice locomotor activity in open-field (OF) test after the 9-days SR ("Stress Relief" trace minerals dietary supplement infused in TMS, trace mineral solution) intake (Experiment 1). TMS, control group of non-stressed mice that drank a water mixed with TMS; TMS-S, control group of mice that underwent 5-min forced swimming stress (FSS) that drank a water mixed with TMS; SR, nonstressed mice that drank water mixed with SR infused TMS; SR-S, FSS mice that drank water mixed with SR infused TMS.

we decided to use 9-day, and also 7-, 14-, 28-, and 32-day, depending on the experiment aim.

First part of the study. Results of the first part of the study, i.e., SR 9-day intake experiment revealed significant SR effect on animal locomotor activity regarding intensity, as well as kind of movement and covered zones. Figure 4 presents examples of images from two sessions of mice activity tracking, where compared to the respective control (TMS), the enhanced effect of SR on mice moving activity, overall zone crossing, and, especially, central zone (CZ) crossing activity under normal environmental white noise condition and after applying of inescapable 5-min swimming stress (red S), is clearly seen.

More detailed analysis of 10 tracking sessions showed (Fig. 5A) that 9-day drinking of SR had a very significant effect on the total distance walked during a 10-min session in $\mathrm{OF}$ in both control and stressed animals (one-way ANOVA, $\left.F_{3,44}=12.14, p<0.0001\right)$.

Compared with TMS no-stress control conditions, FSS caused decrease in mice locomotor activity (TMS-S vs TMS, $p=0.018)$. SR not only reversed the decreased activ- ity to the control level, but resulted in significantly higher activity than in the control (SR-S vs. TMS-S, $p<0.0001$ ). Also in non-stressed animals SR elicited significant increase of motility (SR vs. TMS, $p=0.018$ ). Similar effect was observed for all zone crossings (Kruskal-Wallis statistic = 28.48; TMS-S vs. TMS, $p=0.04$; SR vs. TMS, $p=0.07$; SR-S vs. TMS-S, $p=0.0001$ ) (Fig. 5B), as well as central zone $(\mathrm{CZ})$ crossing (Kruskal-Wallis statistic $=26.8$; SR vs. TMS, $p=0.0006$; SR-S vs. TMS-S, $p<0.0001$ ) (Fig. 5C) and time spent in the central part of arena (Kruskal-Wallis statistic $=21.93$; SR vs. TMS, $p=0.0003$; SR-S vs. TMS-S, $p=0.0002)($ Fig. 5D).

To estimate and compare the effect of SR from ten individual tracking sessions, measurements of each of ten mice from the non-stressed SR group were compared with those of the respective control animal and expressed in $\%$ as a difference (Fig. 6A). The same was done for stressed animals (Fig. 6B).

Figure 6 clearly illustrates the most pronounced SR effects (surrounding with red oval) in normal (A) and stressed animals (B), which include total number of zone entries (N.Ent.), distance walked (Dist.), maximal moving speed
A

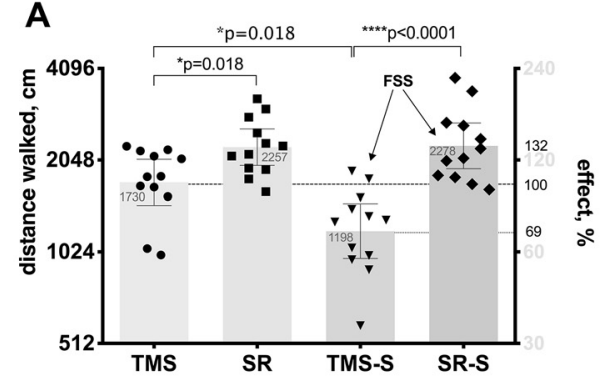

C

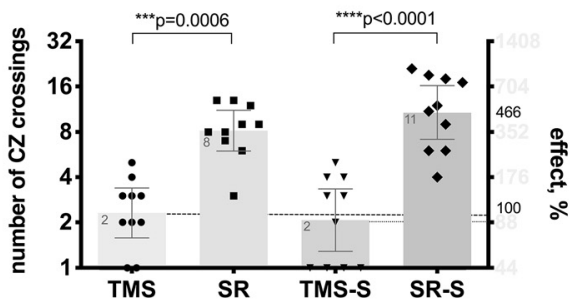

B

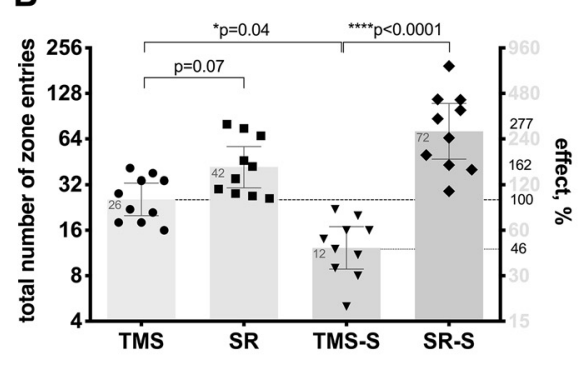

D

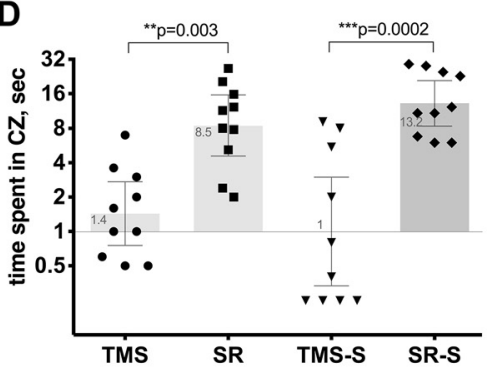

Fig. 5. Effect of 9-day (Experiment 1) oral intake of water mixed with SR ("Stress Relief" trace minerals dietary supplement) infused TMS (trace mineral solution) on locomotor activity of mice in open-field (OF) test. Normal (TMS, SR) and short-term forced swimming stressed (FSS) mice (TMS-S, SR-S). (A) distance walked (one-way ANOVA, $F_{3,44}$ $=12.14, p<0.0001$ ), (B) zone entries (Kruskal-Wallis statistic, 28.48, $p<0.0001$ ), (C) central zone crossings (Kruskal-Wallis statistic, 26.8, $p<0.0001$ ), and (D) spent time there (Kruskal-Wallis statistic, 21.93, $p<$ 0.0001). Between group comparison was done by two-stage step-up method of Benjamin, Krieger, and Yekutieli as a post-hoc test. Fine dotted lines show control levels. The numbers on bar graph represent the mean values. 

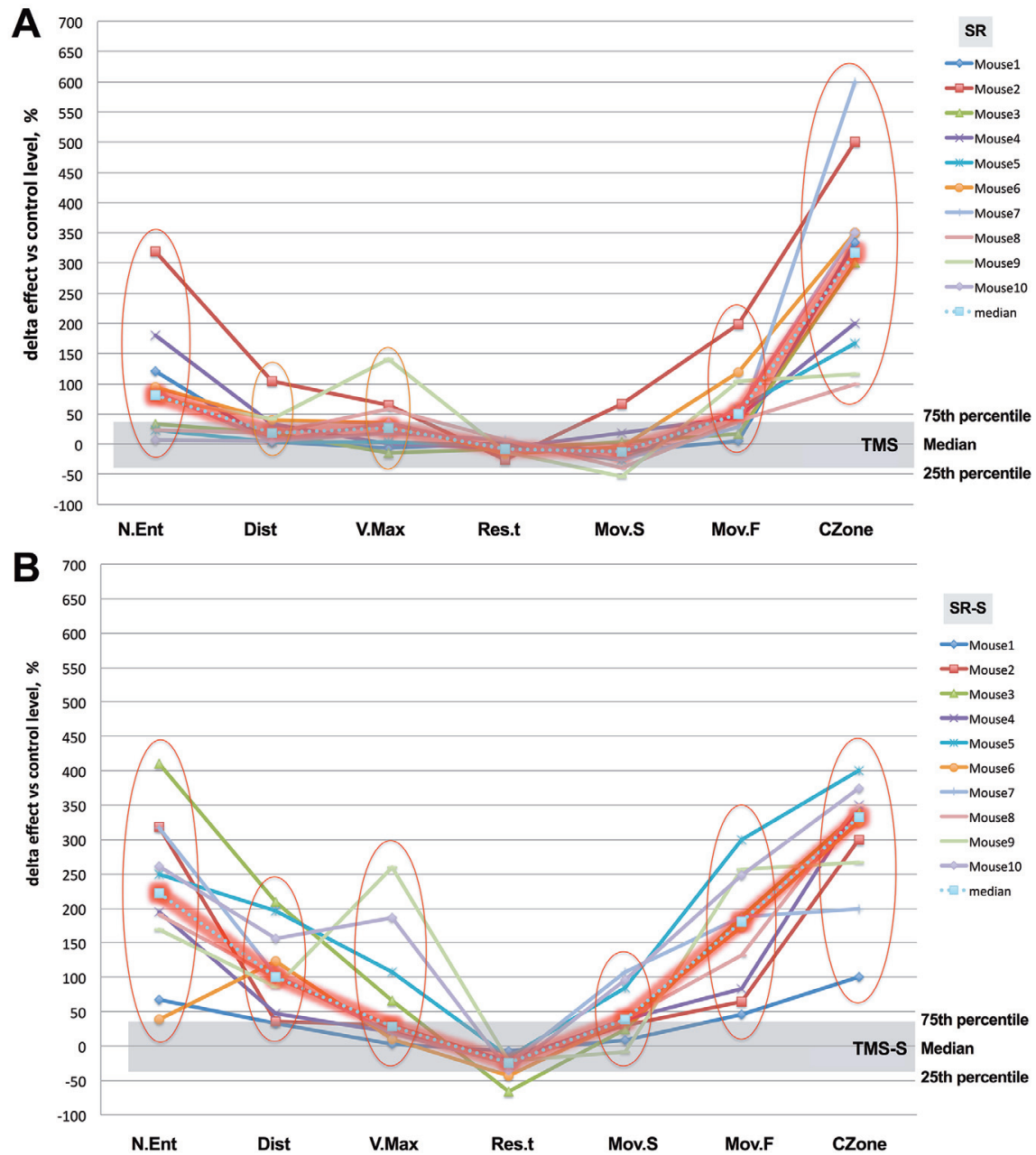

Fig. 6. Open-field (OF) activity spectrum of non-stressed (A) and forced swimming stressed (B) mice with 9-days full access intake of water mixed with of SR ("Stress Relief" trace minerals dietary supplement infused in TMS, trace mineral solution) (Experiment 1). N.Ent, number of entrances (zone crossings); Dist, distance walked; V.Max, maximal velocity; Res.T, resting time; Mov.S, slow movements; Mov.F, fast movements; and CZone, central zone crossings. All of these measurements for each mouse from the SR (A) or SR-S (B) group were compared to that of the corresponding control animal of the respective group (TMS or TMS-S) from each trial. The effect is expressed as \% difference from the individual control. Gray bars represent variability (interquartile range $-25^{\text {th }}-75^{\text {th }}$ percentiles $)$ of median $\left(50^{\text {th }}\right.$ percentile) control level (A - TMS, B - TMS-S) obtained from control animals in 10 separate trials. The most pronounced effects are marked with a red oval. The bold line shows the average effect of measured characteristics in ten SR-receiving mice in (A) non-stressed (SR) and (B) stressed (SR-S) groups and is represented as a median.
(V.Max.), episodes of slow movements (Mov.S.), episodes of fast movements (Mov.F.) and central zone entries (CZone).
In addition, correlation analysis confirmed the presence of sufficient statistically significant effect of 9-days SR intake on activity of stressed fearful mice (Fig. 7), as well as on
A

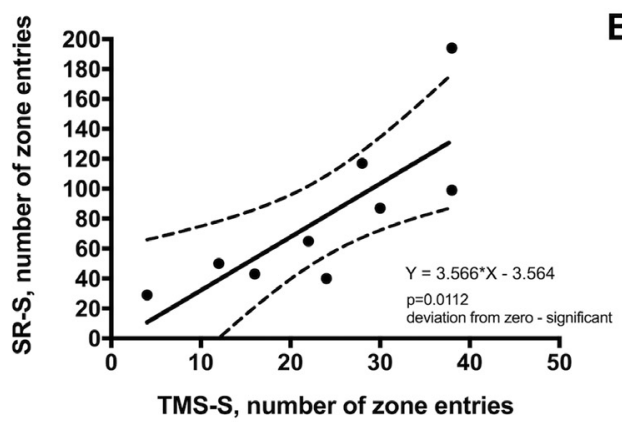

B

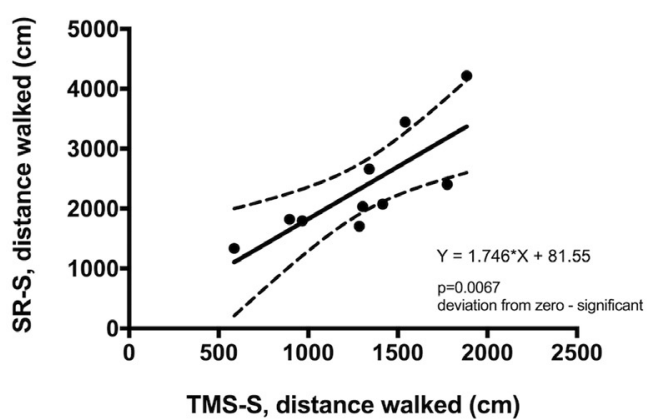

C

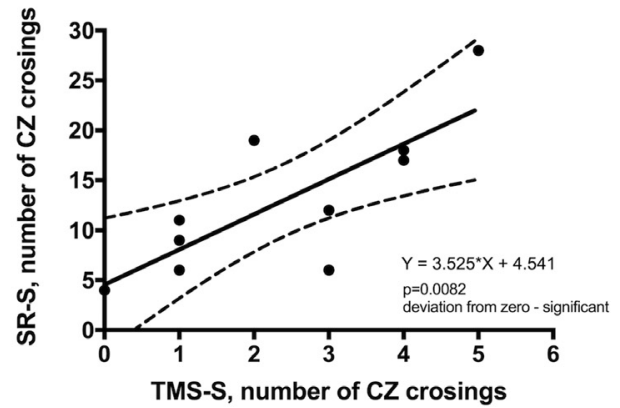

Fig. 7. Examples of positive correlative association between SR ("Stress Relief" trace minerals dietary supplement infused in TMS, trace mineral solution) and control (TMS) groups under forced swimming stress conditions (SR-S and TMS-S) in the 9-day Experiment 1, which illustrate stimulatory effect of SR on A - zone crossings (N.Ent., number of entrances), $\mathrm{B}$ - distance walked (Dist) and C - central zone entrances (CZone) in the open field test. Each dot represents the value of the respective activity of individual mice from group SR-S with the X-axis showing value of the corresponding control group mice (TMS-S). Dashed lines show 95\% confidence bands of the linear regression curve. 



Fig. 8. Examples from tracking sessions of mice locomotor activity in open-field (OF) test from the 7-days Experiment 2. TMS, control non-stressed or TMS-S, control stressed mice that drank water mixed with TMS (trace mineral solution); SR, nonstressed or SR-S, stressed mice that drank water mixed with SR ("Stress Relief" trace minerals dietary supplement) infused in TMS. 1, no stress condition; 2 , stress condition by applying predator odour (cat-rat urine, CRU), in each corner. Arrows show the most visited corner of stress control animals, which is opposite to the corner with the applied stressor agent.

one of normal non-stressed animals (data are not included in this article).

Second part of the study. The second part of the study was done with the aim to explore SR effect on animals with weaker short-term stress conditions, by implementing the well-known rodent predator odour stress environment as a model, with mixed cat/rat urine soaked sawdust in the outer corners of the arena (Fig. 8, green rectangles).

In addition, three experiments (2, 3, 4, as shown in Fig. 1) were conducted to explore the relationship between SR intake duration and effect size. Figure 8 represents examples of images from two sessions of mice activity tracking, where a very pronounced tracking difference between SRreceived and control (TMS) mice (Fig. 8-1), and between similar mice being under predator odour stressful conditions (Figure 8-2) in the 7-day SR intake experiment, are seen. It clearly shows much higher intensity of locomotion, including central zone crossings in non-stressed animals, as well as in animals that received respective stressful stimuli. Control stressed animals (TMS, red CRU) preferred to visit a corner (shows arrow) opposite to that with a cat/rat urine soaked gauze bag. In SR-treated animals, explorative behaviour in general was not affected by this stress agent. As in experiment 1 , more detailed analysis from 10 tracking sessions showed (Fig. 9A) that 7-day drinking of SR had significant effect on total distance walked during a 10-min session in $\mathrm{OF}$ in both control and stressed animals (one-way ANOVA, $\left.F_{3,36}=13.31, p<0.0001\right)$.

Control POS, compared with TMS no-stress, caused a weak but non-significant decrease in mice locomotor activity (TMS-S vs. TMS, $p=0.11$ ), SR reversed the decreased activity to the normal control level and resulted in significantly higher effect than in the stress control group (SR-S vs. TMS-S, $p<0.0001)$. Also in non-stressed animals SR elicited substantial elevation of motility (SR vs. TMS, $p=$ 0.05). A similar effect was observed for all zone crossings (one-way ANOVA, $F_{3,36}=14.46, p<0.0001$; SR vs. TMS, $p=0.003$; SR-S vs. TMS-S, $p=0.0001$ ) (Fig. 9B). The largest effect was observed for Central zone $(\mathrm{CZ})$ crossing (one-way ANOVA, $F_{3,36}=17.58, p<0.0001$; TMS vs. TMS-S, $p=0.035$; SR vs. TMS, $p=0.0001$; SR-S vs. TMS-S, $p<0.0001$ ) (Fig. 9C). Although visits to the "stress" corner decreased in stress control animals, this ef-
A

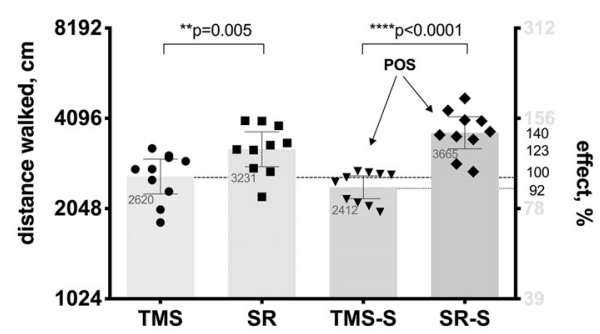

C

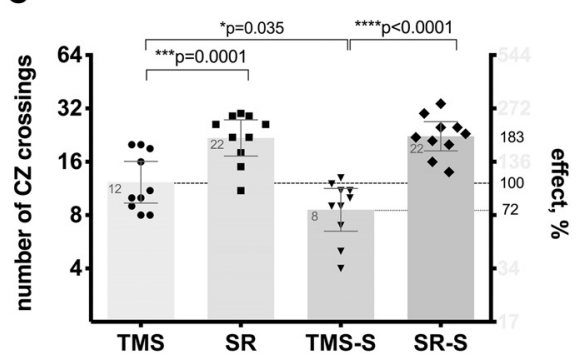

B

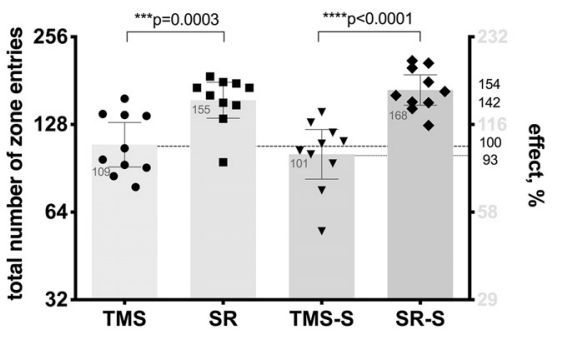

D

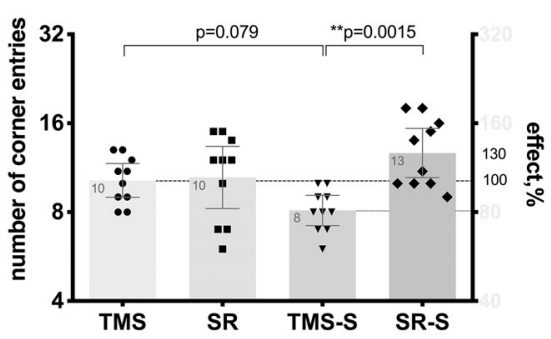

Fig. 9. Influence of 7-day (Experiment 2) oral intake of water mixed with SR ("Stress Relief" trace minerals dietary supplement infused in TMS, trace mineral solution) on locomotor activity of mice in the open-field (OF) test with and without application of cat-rat urine as a predator odour stress (POS) factor. (A) distance walked (one-way ANOVA, $F_{3,36}=13.31, p<$ 0.0001), (B) zone entries (one-way ANOVA, $\left.F_{3,36}=14.46, p<0.0001\right)$, (C) central zone crossings (one-way ANOVA, $F_{3,36}=17.58, p<$ 0.0001 ), and (D) corner zone entries (one-way ANOVA, $F_{3,36}=4.664 ; p=0.0075$ ) in normal and stressed mice in the OF test. Between group comparison was done by two-stage step-up method of Benjamin, Krieger and Yekutieli as a post-hoc test. Fine dotted lines show control levels. The numbers on bar graph represent the mean values. 

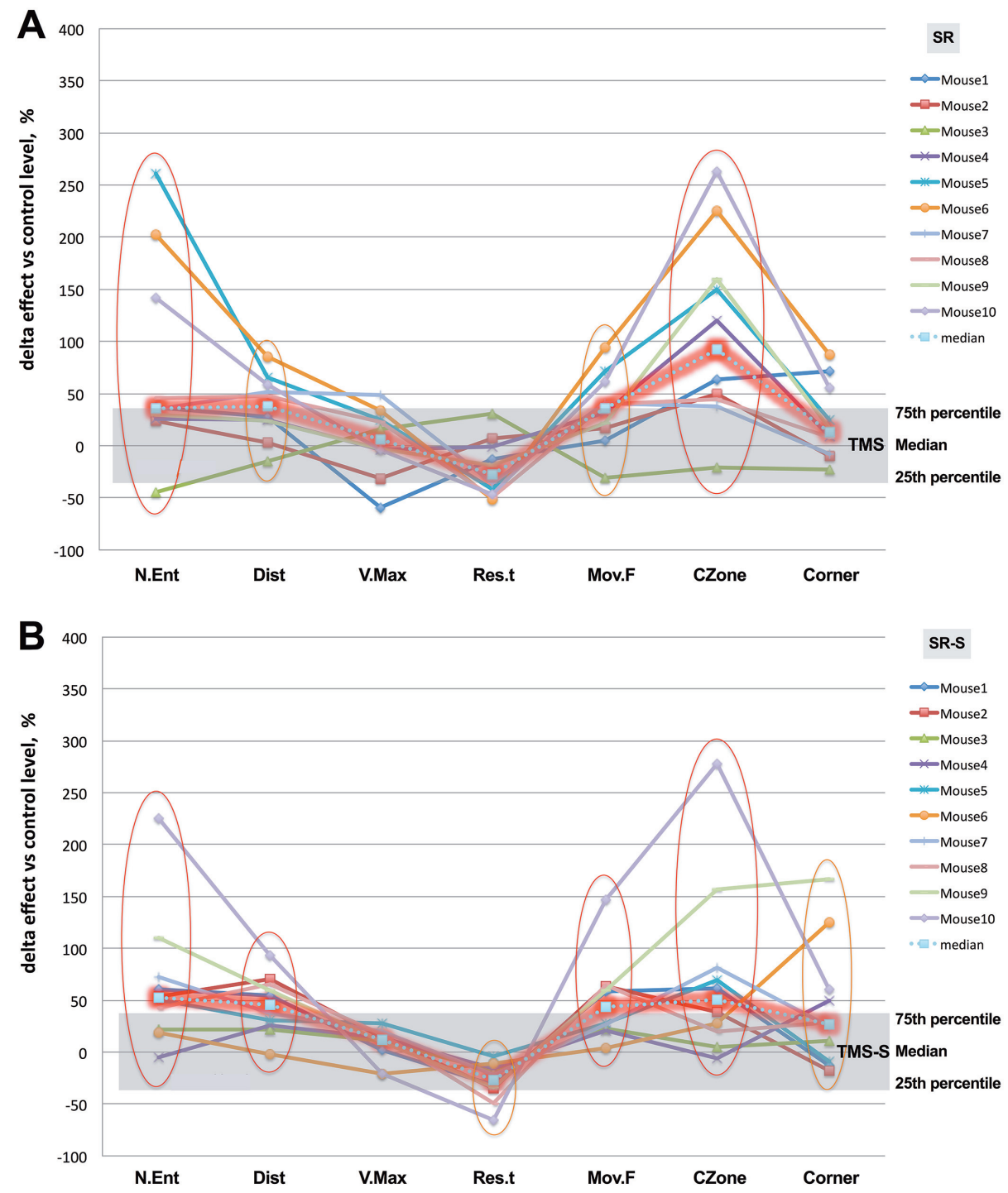

Fig. 10. Open-field (OF) activity spectrum of non-stressed (A) and forced swimming stressed (B) mice with 7-day full access intake of water mixed with SR ("Stress Relief" trace minerals dietary supplement infused in TMS, trace mineral solution) (Experiment 2). N.Ent, number of entrances (zone crossings); Dist, distance walked; V.Max, maximal velocity; Res.T, resting time; Mov.F, fast movements; CZone, central zone crossings; and Corner, corner zone entries. All of these measurements of each mouse from the SR (A) or SR-S (B) group are compared to that of the corresponding control animal of respective group (TMS or TMS-S) from each trial, and effect is expressed as \% difference from the individual control. Gray bars represent variability (interquartile range $-25^{\text {th }}-75^{\text {th }}$ percentiles) of the median ( $50^{\text {th }}$ percentile) control level (A, TMS; B, TMS-S) obtained from control animals of 10 separate trials. The most pronounced effects are marked with a red oval. The bold line shows the average effect of measured characteristics for ten SR-receiving mice in (A) non-stressed (SR) and (B) stressed (SR-S) groups and is represented as median. fect was not statistically significant (TMS vs. TMS-S, $p=$ 0.14). However, SR-treated mice could restore number of visits of the respective corner to the level of the non-stress control and higher (one-way ANOVA, $F_{3,36}=4.664 ; p=$ 0.0075; SR-S vs. TMS-S, $p=0.0015$ ) (Fig. 9D).

Comparing effect of SR from ten individual tracking sessions, measurements of each of ten mice from non-stressed or stressed SR received groups were compared with those of respective control animal and expressed in \% as the difference (Fig. 10A, B). Effect on the investigated was in general similar to that (Fig. 6A, B) obtained from experiment 1 with applied swimming stress factor, but was not as pronounced.

However, the number of zone entries (N.Ent.), distance walked (Dist.), episodes of fast movements (Mov.F.), central zone entries (CZone), and corner entries (Corner) were significantly affected by SR intake. Results acquired from the next two experiments (14-day and 28-day of SR intake) did not reveal significant difference in effect on the main parameters, i.e., distance walked, number of zone entries, central zone and corner entries (Fig. 11A, B, C, D) comparing to 7-day intake.

SR intake during 7, 14 and 28 days affected behaviour of animals subjected to mild short-term predator odour stress in a similar way without substantial difference, except in the subject factor (two-way ANOVA, interaction factor $F_{6,108}=$ $0.304, p=0,934$; subject factor $F_{3,108}=14.38, p<0.0001$; time factor $F_{2,108}=0.024, p=0.977$ ), which confirmed all observed effects presented in Figure 9 and Figure 10.

Third part of the study. In the last part of our study we extended the SR consumption to 32 days and combined both stress factors, forced swimming and cat/rat urine, on day 32. Results show (Fig. 12) that effect of 32-day SR intake on combined stressed animal behaviour in OF was very similar to that obtained in experiment 1 (where one stress factor inescapable swimming was applied, Fig. 5), but more pronounced. Detailed analysis of 10 tracking sessions showed (Fig. 11A, B, C, D) that combination of two stress factors significantly decreased all four main characteristics used in this study to assess effect of SR on mice behaviour (TMS 
A

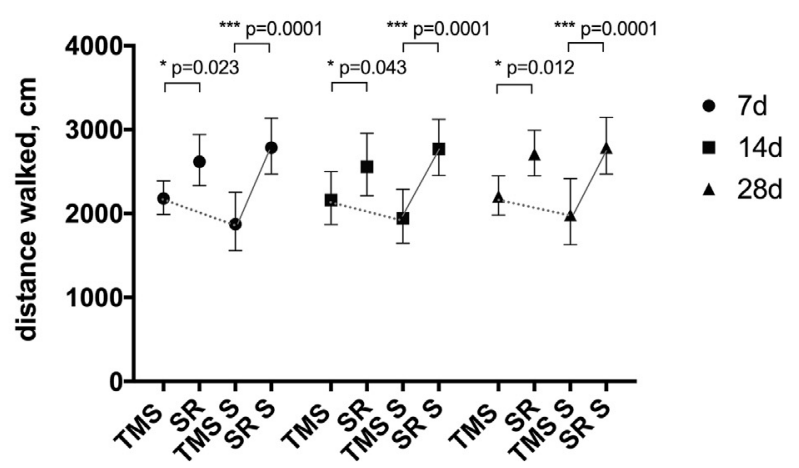

C

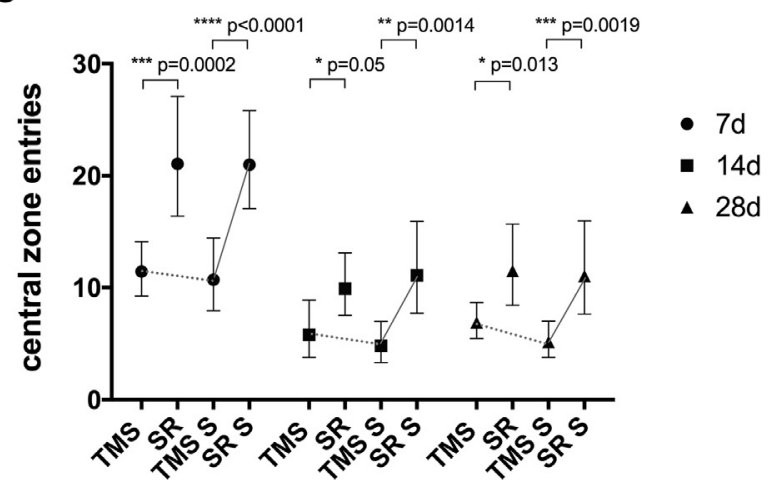

B

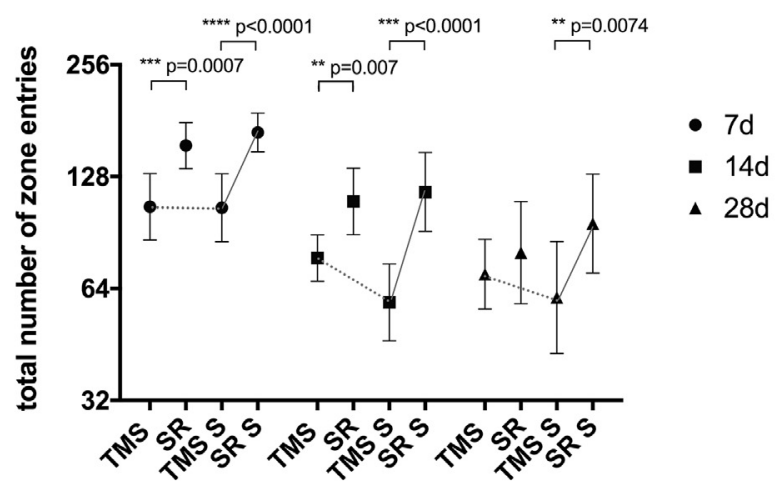

D

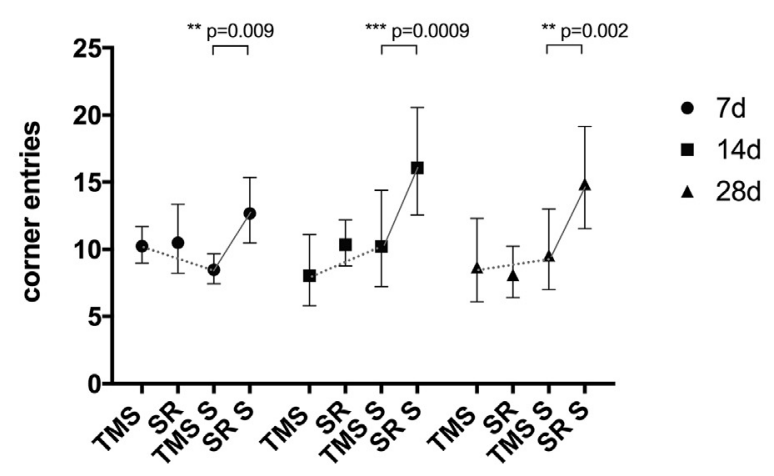

Fig. 11. Comparison of the effect of 7-, 14-, and 28-days' oral intake of SR ("Stress Relief" trace minerals dietary supplement infused in TMS, trace mineral solution) (Experiment 2, 3,4) on locomotor activity of mice in OF under normal and predator odour stress (POS) conditions. (A) distance walked, (B) zone entries, (C) central zone and (D) corner entries. Between group comparison was done by two-stage step-up method of Benjamin, Krieger, and Yekutieli as a post-hoc test.

vs. TMS-S. - (A) $p=0.047$; (B) $p=0.047$; (C) $p=0.05$; (D) $p=0.03$ ).

Combined 32-day drinking of SR had a very significant effect on total distance walked during the 10-min session in OF in both control and stressed animals (one-way ANOVA, $\left.F_{3,36}=26.04, p<0.0001\right)$. SR-treatment could not only reverse decreased activity to the control level, but also resulted in significantly higher effect than in the control one (SR-S vs. TMS-S, $p<0.0001$ ). In non-stressed animals SR elicited significantly higher level of walking activity (SR vs. TMS, $p=0.0002$ ) (Fig.12A).

Similar effect was observed for all zone crossings (one-way ANOVA, $F_{3,36}=20.06, p<0.0001$; SR vs. TMS, $p=$ 0.0003; SR-S vs. TMS-S, $p<0.0001$ ) (Fig. 12B), as well as central zone $(\mathrm{CZ})$ crossings (one-way ANOVA, $F_{3,36}=$ 16.29, $p<0.0001$; SR vs. TMS, $p=0.0003$; SR-S vs. TMS-S, $p<0.0001$ ) (Fig. 12C) and "stress" corner visiting (one-way ANOVA, $F_{3,36}=7.069, p=0.0007$; SR-S vs. TMS-S, $p<0.001$ ) (Fig. 12D).

After the OF session of the last experiment, a blood glucose test was performed. The obtained results showed (Fig. 13) that combined FSS/POS stress condition caused a higher blood glucose level, while the 32-day SR-treatment resulted in a normal glucose level, similar to that of control non- stressed animals. SR did not affect blood glucose in nonstressed mice.

\section{DISCUSSION}

The results of this complex study showed that "Stress Relief" dietary supplement formula (SR) can activate general locomotor (walking) activity in C57B16 male mice after repeated intake of dissolved trace minerals infused with Stress Relief formula. The common effect was repeatable, as similar effect was observed in all five experiments. However, it was not significantly affected by SR-intake duration (7-, 9-, 14-, 28-, or 32-days). Therefore, the optimal usage might be 7-9 days, but this is still under discussion. It is not yet known how long an activation effect can be observed after discontinuation of SR one-week usage, which should be investigated in other additional experiments. However, it is obvious that SR possess some ergo-tropic features that serve as the basis of fight-flight response to acute or immediate stress mobilising energetic resources to active behaviour (Figs. 4, 5, 6A, 8, 9, 10A, 11, 12). A similar even more pronounced effect was observed in animals that were exposed to short-term stress (five minutes of forced swimming, or 10 min exposure to predator odours, or combination of both stress factors). SR not only reversed stressinduced hypomotility and activated locomotor functions of 
A
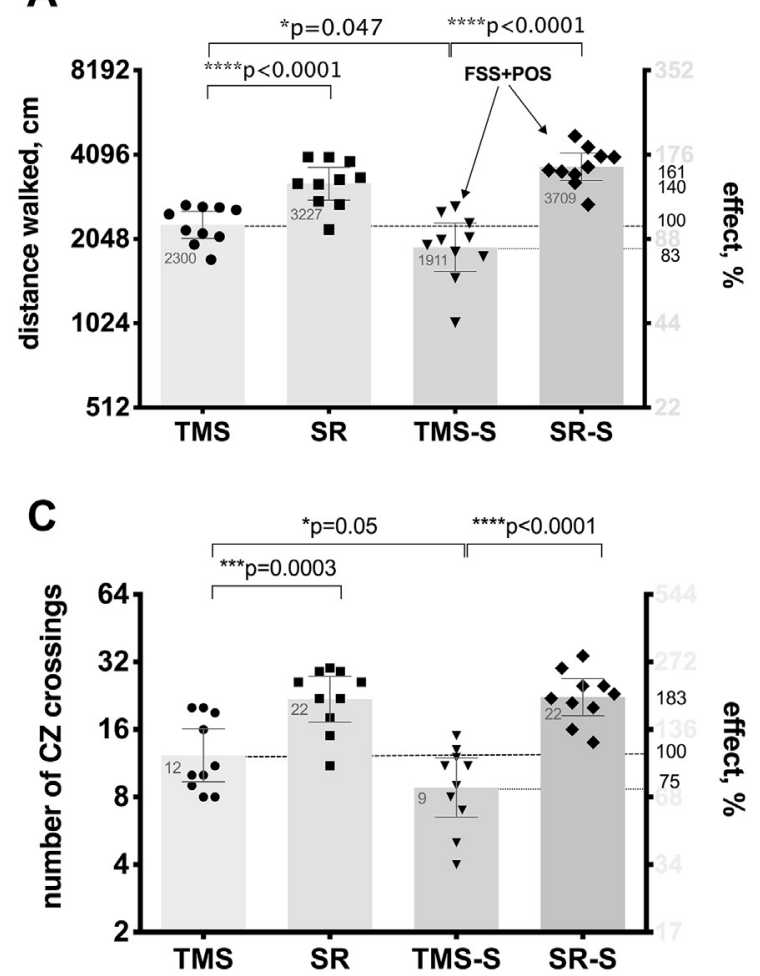

B

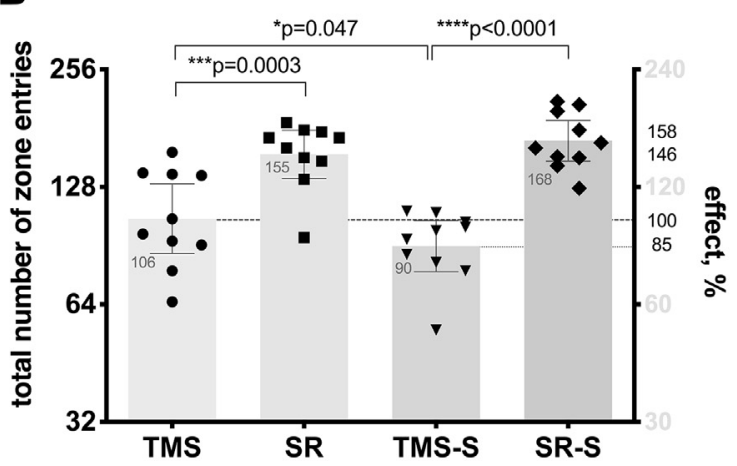

D

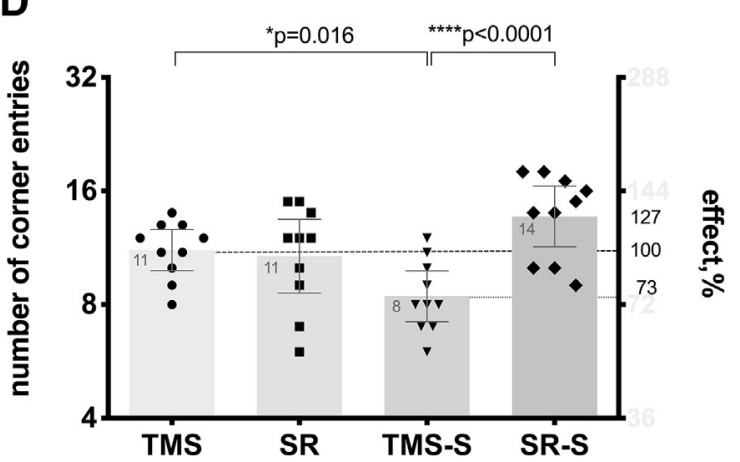

Fig. 12. Effect of 32-day (Experiment 5) oral intake of water mixed with SR ("Stress Relief" trace minerals dietary supplement infused in TMS - trace mineral solution) on locomotor activity of mice in open-field (OF) test with and without application of combined forced swimming (FSS) and predator odour stress (POS). (A) distance walked (one-way ANOVA, $F_{3,36}=26.04, p<0.0001$ ), (B) zone entries (one-way ANOVA, $F_{3,36}=20.06, p<0.0001$ ), $(\mathrm{C})$ central zone crossings (one-way ANOVA, $F_{3,36}=16.29, p<0.0001$ ) and (D) corner entries (one-way ANOVA, $F_{3,36}=7.069, p=0.0007$ ). Between group comparison was done by two-stage step-up method of Benjamin, Krieger, and Yekutieli as a post-hoc test. Fine dotted lines show control levels. The numbers on bar graph represent the mean values.

animals, but also increases central zone crossing activity, time spent in the central zone, and increased number of visits to the "stress" corner visiting where the odour stress factor was applied (Figs. 4, 5, 6B, 7, 8, 9, 10B, 11, 12), indicating stress-suppressive action. The presented set of observations indicates that the "Stress Relief" subtle energy pattern has a fear- and stress-reducing effect in treated animals under different stressful situations, which is also clearly and strongly supported by results showing complete normalisation of stress-induced elevation of blood glucose level (Fig. 13).

It has been suggested that the rodent forced swim test used as one of stress models in this study measures stress-coping strategy, not depression-like behaviour (Commons et al., 2017). Therefore, it can be assumed that SR results in stress-protective features, as well as some anxiety-suppressive, psycho-stimulating, psycho-activating (the motion trajectory pattern closely reminiscent that of psycho-stimulant agent amphetamine - Gould et al., 2009) features, which are vital force activating properties. The effects observed in this study, especially normalisation of glucose level after SR usage that was elevated by stress factors, serves as the basis of an argument to establish this assumption. It is well known that stress underlies anxiety and affective disorders,

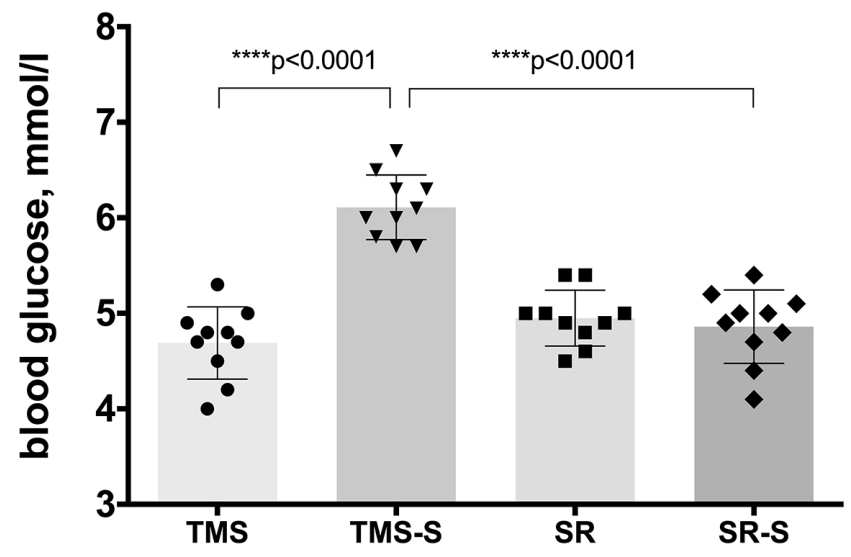

Fig. 13. Stress-induced rise of blood glucose and its normalisation after SR ("Stress Relief" trace minerals dietary supplement infused in TMS, trace mineral solution) 32-day (Experiment 5) intake (one-way ANOVA, $F_{3,36}=$ 34.23, $p<0.0001$ ). Between group comparison was done by two-stage step-up method of Benjamin, Krieger, and Yekutieli as a post-hoc test. TMS, non-stress control; TMS-S, stress control.

including depression etc. (Hefner and Holmes, 2007). However, SR fear-reducing and anti-stress activities reflected in all results of this study indicate that SR formula supports healthy functioning of the nervous system, maintaining high vitality without producing a sedative effect. 
It is known that chronic stress can lead to an augmented loss of neurons - a primary factor in the accelerated development of many neurodegenerative diseases (Ritchie et al., 2004; Bao et al., 2008, Kunimoto et al., 2010) and this could facilitate development of some kind of depressions. In fact, currently there are several classes of antidepressant drugs available, but only $50 \%$ of patients show a satisfying response to them and about $70 \%$ fail to achieve complete remission (Kemp et al., 2008; Bet et al., 2013) and no clear predictors of treatment response are available. However, modalities of "energy medicine", also known as vibrational medicine, have been proposed for treating stress (Gerber, 2001; Oschman, 2003; Rindfleisch, 2010). Issues of such approaches are more and more often being discussed by leading specialists at different summits and meetings (Anonymous, 2017d; Anonymous, 2017g). Energy medicine, one of the fastest growing complementary medicine therapies (Gerber, 2001; Oschman, 2003; Rindfleish, 2010) is based on thousands of years of experience and practice in the Eastern philosophical and medical traditions. These ancient systems of medicine emphasise the importance of balanced "life force" energy flows, both inside and outside our bodies, for the maintenance of our health (Oschman, 2003; Rindfleish, 2010; Mayor and Micozzi, 2011). This "life force" is the most often called "subtle energy" by modern frontier scientists (Kronn et al., 2001; Wilber, 2005; Swanson, 2009; Rindfleish, 2010). Studies on biological communications on the cellular level, however, mainly focus on chemical signals. As organisms are extremely complex, more different kinds of signals may exist in the process of cell communication (Han et al., 2011). One of the most probable candidates for an alternative form of how an organism can communicate is electromagnetic radiation, which widely exists in cells, tissue, organisms and their surroundings. It has also been proposed that quantisation of electromagnetic radiation as quantum could serve as a biological messenger (Han et al., 2011). Experimental evidence for non-chemical and non-contact cell-to-cell communication is described in scientific literature that can be traced back to almost 100 years ago and has also been reported by many recent studies (Scholkmann et al., 2013). However, there might be other physical force(s) and energy flows (also described as "subtle energy"), forces beyond the atomic level, that are not explained by electromagnetism principles, which are not detectable by contemporary sophisticated measurement tools. The effect of these subatomic events can be fixed, partly indirectly, by changes of behaviour, as well as by biochemical or physiological responses of living beings, including plants. The general hypothesis about the nature of "subtle energy" and its relations to forces considered by Eastern traditional medicine and philosophy ("chi" in China, "prana" in India) and the forces known to modern science have been discussed by some authors (Kronn, 2003; Wilber, 2005; Swanson, 2009; Kronn, 2009). "Subtle energy" as the $5^{\text {th }}$ force of the Universe has been hypothesised about (Kronn and Jones, 2011). The know-how methodology of Dr. Yury Kronn (realised by Vital Force Technology) for capturing (by electromagnetically controlled plasma of ionised gasses) different subatomic or "subtle energy" patterns that have been generated by all living and not living subjects could provide new opportunities for maintaining normal body functioning. Results of our study provide a very feasible argument for this assumption, as well as provide scientific support for the previously observed effects of other "energy formulas", for example, regulation of the autonomic nervous system, increase of the survival rate of cells damaged by gamma radiation as well as maintaining the viability and mitochondrial membrane potential in the presence of mitochondrial poison, and even ability to influence gene expression (Anonymous, 2017a).

In conclusion, by applying modern neuroscience-approved research methods, including standard laboratory animals and appropriate models and tests, we are able to demonstrate that "Stress Relief formula" (water additivesminerals) processed by know-how way in Vital Force Technology using Dr. Yury Kronn method has effect on the animal behaviour. It reduces anxiety, possesses ergo-tropic features and has anti-stress activity. Furthermore, detailed and expanded research on these topics could provide more indisputable evidence of substantial effects of possible "subtle energy" and its preparations (as dietary supplements) indirectly or directly on living organisms, where SR effects could be compared with respective known medications like anxiolytics as reference drugs.

\section{ACKNOWLEDGEMENTS}

This work was partly supported by a local research grant from the Department of Pharmacology, Faculty of Medicine, University of Latvia. The authors would like to acknowledge Dr. Yury Kronn for provision of the Stress Relief energy pattern.

\section{CONFLICT OF INTEREST}

No competing financial interests exist.

\section{REFERENCES}

Andreescu, C., Mulsant, B. H., Emanuel, J. E. (2008). Complementary and alternative medicine in the treatment of bipolar disorder: A review of the evidence. J. Affect. Disord., 110, 16-26.

Anonymous (2013). The Structuring Effect of Vital Force Energetic Formulas in Water Solutions Verified by Gas Discharge Visualization (GDV) Camera. Available from:

http://www.vitalforcetechnology.com/uploads/images/downloads/ Measuring-Effects-with-GDV.pdf (accessed 4 August 2017).

Anonymous (2017a). Bioseb Website. See:

https://www.bioseb.com/bioseb/anglais/default/index.php

Anonymous (2017b). MGI (Mouse Genome International) database. Mouse facts. Available from:

http://www.informatics.jax.org/mgihome/other/mouse_facts1.shtml 2017 (accessed 4 August 2017).

Anonymous (2017c). PennState Animal Resource Program. (2017). Porsolt Forced Swim Test. Available from:

http://www.research.psu.edu/arp/experimental-guidelines/ 
rodent-behavioral-tests-1/porsolt-forced-swim-test.html (accessed $4 \mathrm{Au}$ gust 2017)

Anonymous (2017d). Quantum World TV. Kronn Y: Introduction to Energy Medicine. http://quantumworld.tv/videos/intro-to-energy-medicine/ (accessed 4 August 2017.

Anonymous (2017e). Vital Force Technology website. Available from: http://www.vitalforcetechnology.com/research-library/advanced-research (accessed 4 August 2017).

Anonymous (2017f). Waters website. http://www.waters.com/waters/en_LV/Original-UPLC-UHPLC-system-with-sub-2-micron-particletechnology-for-separations/nav.htm?cid=514207\&locale=en_LV) (accessed 4 August 2017)

Anonymous (2017g). World Summit of Integrative Medicine. Speaker Line-Up. Available from:

https://worldsummitintegrativemedicine.com/speakers/ (accessed $4 \mathrm{Au}-$ gust 2017).

Axe, J. (2010). Conventional Medicine is the leading cause of death. Available from:

http://draxe.com/conventional-medicine-is-the-leading-cause-of-death/ (accessed 4 August 2017).

Bao, A.-M., Meynen, G., Swaab, D. F. (2008). The stress system in depression and neurodegeneration: Focus on the human hypothalamus. Brain Res. Rev., 57, 531-553.

Berry, A., Bellisario, V., Capoccia, S., Tirassa, P., Calza, A., Alleva, E., Cirulli, F. (2012). Social deprivation stress is a triggering factor for the emergence of anxiety- and depression-like behaviours and leads to reduced brain BDNF levels in C57BL/6J mice. Psychoneuroendocrinology, 37, $762-772$.

Bet, P. M., Hugtenburg, J. G., Penninx, B. W. J. H., van Balkom, A., Nolen, W. A., Hoogendijk, W. J. G. (2013). Treatment inadequacy in primary and specialized care patients with depressive and/or anxiety disorders. Psychiatry Res., 210, 594-600.

Bussey, T. J., Holmes, A., Lyon, L., Mar, A. C., McAllister, K. A., Nithianantharajah, J., Oomen, C. A., Saksida, L. M. (2012). New translational assays for preclinical modelling of cognition in schizophrenia: The touchscreen testing method for mice and rats. Neuropharmacology, 62, 1191-1203.

Commons, K. G., Cholanians, A. B., Babb, J. A., Ehlinger, D. G. (2017). The rodent forced swim test measures stress-coping strategy, not depression-like behavior. ACS Chem. Neurosci., 8 (5), 955-960.

Cryan, J. F., Holmes, A. (2005). The ascent of mouse: Advances in modelling human depression and anxiety. Nat. Rev. Drug Discov., 4, 775-790.

Forster, A. J., Murff, H. J., Peterson, J. F., Gandhi, T. K., Bates, D. W. (2003). The incidence and severity of adverse events affecting patients after discharge from the hospital. Ann. Intern. Med., 138 (3), 161-167.

Gerbarg, P. L., Brown, R. P. (2001). Phytomedicines for prevention and treatment of mental health disorders. Psych. Clin. North Amer., 36, 37-47.

Gerber, R. (2001). Vibrational Medicine. Bear \& Company. 608 pp.

Gould, T. D., Dao, D. T.,, Kovacsics, C. E. (2009). The Open Field Test. In: Gould, T. D. (Ed.). Neuromethods V42, Mood and Anxiety Related Phenotypes in Mice. Humana Press. pp. 1-20.

Han, J., Yang, M., Chen, Y. (2011). Quantum: May be a new-found messenger in biological systems. BioScience Trends, 5 (3), 89-92.

Hefner, K., Holmes, A. (2007). Ontogeny of fear-, anxiety- and depression-related behaviour across adolescence in C57BL/6J mice. Behav. Brain Res., 176, 210-215.

Heredia, L., Torrente, M., Colomina, M. T., Domingo, J. L. (2014). Assessing anxiety in C57BL/6J mice: A pharmacological characterization of the open-field and light/dark tests. J. Pharmacol. Toxicol. Meth., 9, $108-114$
Jafari, Z., Kolb, B. E., Mohajerani, M. H. (2017). Effect of acute stress on auditory processing: A systematic review of human studies. Rev. Neurosci. 28 (1), 1-13.

Kemp, A. H., Gordon, E., Rush, A. J., Williams, L. M. (2008). Improving the prediction of treatment response in depression: Integration of clinical, cognitive, psychophysiological, neuroimaging, and genetic measures. CNS Spectrums, 13, 1066-1086.

Kim, Y. N., Cho, S.-H. (2014). A survey of complementary and alternative medicine practitioner's perceptions of evidence-based medicine. Eur. J. Integr. Med.. 6 (2), 211-219.

Kronn, Y., Eanes, R., Marongelle, J. (2001). Subtle energy and energy medicine: New paradigms, new technologies, new possibilities. Available from: http://vitalforcetechnology.com/uploads/images/downloads/

Subtle-Energys-Interaction-with-the-Human-Body.pdf (accessed $4 \mathrm{Au}$ gust 2017)

Kronn, Y. (2003). Energy — the missing link to health. New effective energy medicine tools. Science of whole person healing. In: Proceedings of the First Interdisciplinary International Conference, 28-30 March 2003, Bethesda, Maryland. Rustom Roy (Ed.), iUniverse, Inc., Lincoln, NE, pp. 157-171.

Kronn, Y. (2009). Subtle Energy, the Universe and Us. The Science and Theory behind Vital Force Technology. Available from:

http://www.energytoolsint.com/wp-content/uploads/2011/10/Subtle-Energy-The-Universe-and-Us.pdf (accessed 4 August 2017)

Kronn, Y., Jones, J. (2011). Experiments on the Effects of Subtle Energy on the Electro-Magnetic Field. Is Subtle Energy the $5^{\text {th }}$ Forcre of the Universe? Available from:

http://www.goodhealthfrominsideout.com/pdf/emfdoc1.pdf (accessed 4 August 2017)

Kunimoto, S., Nakamura, S., Wada, K., Inoue, T. (2010). Chronic stress-mutated presenilin 1 gene interaction perturbs neurogenesis and accelerates neurodegeneration. Exper. Neurol., 221, 175-185.

Lu, Z. (1997). Scientific Qigong Exploration. The Wonders and Mysteries of Qi. Amber Leaf Press, Malvern, PA. 404 pp.

Luo, L. (2016). Chapter 6. Olfaction, Taste, Audition, and Somatosensation. In: Luo, L. (Ed.). Princ. Neurobiol. Taylor \& Francis Group Publ., Garland Science, New York, pp. 207-275.

Mao, Q.-Q., Xian, Y.-F., Ip, S.-P., Tsai, S.-H., Che, C.-T. (2010). Long-term treatment with peony glycosides reverses chronic unpredictable mild stress-induced depressive-like behaviour via increasing expression of neurotrophins in rat brain. Behav. Brain Res., 210, 171-177.

Marzotto, M., Conforti, A., Magnani, P., Zanolin, M. E., Bellavite, P. (2012). Effects of Ignatia amara in mouse behavioural models. Homeopathy, 101, $57-67$

Mayor, D. F., Micozzi, M. S. (2011). Energy Medicine: East and West. Churchill Livingston. 420 pp

Null, G., Dean, C., Feldman, M., Rasio, D., Smith, D. (2006). Death by Medicine. Life Extension Magazine, August. Available from: http://www.lef.org/magazine/mag2006/aug2006_report_death_01.htm ?source $=$ search $\&$ key $=$ death $\% 20$ by $\% 20$ medicine (accessed 4 August 2017).

Oschman, J. L. (2016). Energy Medicine: The Scientific Basis. Elsevier Science. $359 \mathrm{pp}$

Qi, X., Lin, W., Li, J., Li, H., Wang, W., Wang, D., Sun, M. (2008). Fluoxetine increases the activity of the ERK-CREB signal system and alleviates the depressive-like behaviour in rats exposed to chronic forced swim stress. Neurobiol. Dis., 31, 278-285.

Rao, M. N., Slawecki, T. M., Hoover, M. R., Roy, R. (2008). Characterization and properties of structured waters. "Materials Day" at the Materials Research Institute, Penn State University, 15 April. Available from: http://www.personal.psu.edu/ tms9/water.html (accessed 4 August 2017). 
Rindfleisch, J. A. (2010). Biofield Therapies: Energy Medicine and Primary Care. Primary Care: Clinics in Office Practice, 37, 165-179.

Ritchie, L., De Butte, M., Pappas, B. A. (2004). Chronic mild stress exacerbates the effects of permanent bilateral common carotid artery occlusion on CA1 neurons. Brain Res., 1014, 228-235.

Scholkmann, F., Fels, D., Cifra, M. (2013). Non-chemical and non-contact cell-to-cell communication: A short review. Amer. J. Transl. Res., 5 (6), 586-593.

Smith, D. G., Davis, R. J., Gehlert, D. R., Nomikos, G. G. (2006). Exposure to predator odour stress increases efflux of frontal cortex acetylcholine and monoamines in mice: Comparisons with immobilization stress and reversal by chlordiazepoxide. Brain Res., 1117, 24-30.

Sonnentag, S., Fritz, C. (2006). Endocrinological processes associated with job stress: Catecholamine and cortisol responses to acute and chronic stressors. In: Perrewe, P. L., Ganster, D. C. (Eds.). Research in Occupational Stress and Well-being. Elsevier, pp. 1-59.

Staples, L. G. (2010). Predator odour avoidance as a rodent model of anxiety: Learning-mediated consequences beyond the initial exposure. Neurobiol. Learning Memory, 94, 435-445.

Swanson, C. (2009). Life Force, the Scientific Basis: Breakthrough Physics of Energy Medicine, Healing, Chi and Quantum Consciousness. Poseidia Press. 720 pp. van Reedt Dortland, A. K. B., Vreeburg, S. A., Giltay, E. J., Licht, C. M. M., Vogelzangs, N., van Veen, T., de Geus, E. J. C., Penninx, B. W. J. H., Zitman, F. G. (2013). The impact of stress systems and lifestyle on dyslipidemia and obesity in anxiety and depression. Psychoneuroendocrinology, 38, 209-218.

Wahner-Roedler, D. L., Lee, M. C., Chon, T. Y., Cha, S. S., Loehrer, L. L., Bauer, B. A. (2014). Physicians' attitudes toward complementary and alternative medicine and their knowledge of specific therapies: 8-Year follow-up at an academic medical center. Complem. Ther. Clin. Practice, 20, $54-60$.

Wallace, D. (2012). Examining fear and stress as mediators between disorder perceptions and personal health, depression, and anxiety. Soc. Science Res., 41, 1515-1528.

Wardle, J. L., Adams, J. (2014). Indirect and non-health risks associated with complementary and alternative medicine use: An integrative review. Eur. J. Integr. Med. 6 (4), 409-422.

Wilber, K. (2005). Toward a comprehensive theory of subtle energies. Explore, 1 (4), 252-270.

Young, J. W., Minassian, A., Paulus, M. P., Geyer, M. A. Perry, W. (2007). A reverse-translational approach to bipolar disorder: Rodent and human studies in the Behavioral Pattern Monitor. Neurosci. Biobehav. Rev., 31, 882-896.

Received 30 August 2017

Accepted in the final form 16 February 2018

Published online 6 July 2018

\section{PĀRTIKAS PIEDEVAS “STRESS RELIEF” IZVĒRTĒJUMS SAISTĪBĀ AR DZĪVNIEKU STRESA LĪMENI UN LOKOMOTORO AKTIVITĀTI}

Jaunu mazkaitīgu nemedikamentozu pieeju meklējumi attiecībā uz dažādu organisma disfunkciju profilaksi un ārstēšanu joprojām ir veterināru, ārstu un pētnieku uzmanības centrā. Šajā pētījumā ir apkopoti rezultāti par komerciālo "smalkās enerğijas" pārtikas piedevas "Stress Relief" (SR) iedarbības izpēti uz peḷu uzvedību trijos dažāos akūtos īstermiṇa stresa apstākḷos. Tika veikti pieci eksperimenti, un katrā no tiem 40 dzīvniekus pēc nejaušības principa sadalīja četrās (I-IV) grupās, kur I un II grupas dzīvniekiem netika piemērots stress, III un IV — dzīvnieki tika pakḷauti stresam, savukārt I un III — tie dzēra ūdeni ar mineralizēta ūdens piedevu (trace mineral solution), bet II un IV — dzēra ūdeni ar SR piedevu. Kā stresa faktors pelēm tika izmantota dzīvnieku piespiedu peldēšana, grauzēju plēsēju smarža vai abi faktori kopā. Atklāta lauka testā (open field) ar specializētu videoreǵistrācijas sistēmu SMART tika fiksēta un analizēta lokomotorā aktivitāte normālām pelēm un tām, kas tika pakḷutas īslaicīgam stresam. Pēdējāe eksperimenta beigās tika arī mērīts glikozes līmenis asinīs. SR visos stresa modeḷos uzrādīja stresa izsauktās kustību aktivitātes samazināšanās normalizāciju un pat aktivāciju attiecībā pret kontroli — kopējais noskrietais attālums bija gandrīz dubultojies $(p<0,0001)$, centrālās zonas apmeklējumi un pavadītais laiks tajā bija 2-4 reizes lielāks nekā stresa kontroles grupā (attiecīgi, $p<0,0001$ un $p=0,0002$ ), strauju kustību un maksimālo àtrumu epizodes palielinājās par 50-200\%, tika sasniegta piln̄̄ga stresa inducêtā paaugstinātā glikozes līmeņa normalizācija asin̄̄s $(p<0,0001)$. Šie efekti ir būtiski un atkārtojami, liecinot par SR bailes un stresu samazinošu darbību. Ar iegūtajiem rezultātiem pirmo reizi tiek demonstrēts, ka, izmantojot laboratorijas dzīvniekus, var novērot un objektīvi fiksēt daḷēji netiešu "smalkās enerğijas" ietekmi uz dzīvām būtnēm. 